\title{
Standardisation of the quantitative determination of antinuclear antibodies (ANAs) with a homogeneous pattern*
}

\author{
T E W FELTKAMP ${ }^{1}$ F KLEIN, ${ }^{2}$ AND M B J A JANSSENS 3
}

From the ${ }^{1}$ Department of Autoimmune Diseases of the Central Laboratory of the Netherlands Red Cross $\vec{\nexists}$ Blood Transfusion Service, PO Box 9190, 1006 AD Amsterdam, The Netherlands; the ${ }^{2}$ Department of ${ }_{\sigma}$ Epidemiology, Medical Faculty, Erasmus University, Rotterdam, The Netherlands; the ${ }^{3} T N O$, Rheumatic Diseases Research Committee, Division of Health Research, Rijswijk, The Netherlands

SUMMARY The results of antinuclear antibody tests using the indirect immunofluorescence $\mathscr{C}_{\circ}$ technique may be reported as a description of the pattern and the intensity of fluorescence응 obtained at a certain dilution. If quantitative results are required titration is necessary. Such $\rightarrow$ titrations may vary greatly between different laboratories. The present study involving $26 z$ laboratories shows an improvement of interlaboratory comparability for the homogeneous fluorescence pattern when a common reference serum is used. Cultured cells as substrate appear 3 to give better quantitative agreement than rat liver sections. National reference sera should be standardised in items of the appropriate WHO reference preparation.

Key words: international units, reference preparations.

In the late 'sixties and early 'seventies the need for standardisation of the immunofluorescence technique (IFT) was expressed at several international meetings. ${ }^{1-3}$ At one of these Anderson et al reported a study of a proposed research standard for antinuclear factor-66/233 (homogeneous). ${ }^{4}$ This material was subsequently adopted by WHO as an international standard and should therefore permit quantitative expression of antinuclear antibody (ANA) levels in international units (IU) in the same way as was advocated for rheumatoid factors. ${ }^{5}$

Although the use of such a standard may reduce interlaboratory variation, many laboratories express quantitative results of ANA determinations by testing only one or two serum dilutions-for example, 1:10 and 1:100-quantifying the antibody

\footnotetext{
Accepted for publication 7 April 1988.

Correspondence to Professor T E W Feltkamp, c/o Publication Secretariat, Central Laboratory of the Netherlands Red Cross Blood Transfusion Service, PO Box 9406, 1006 AD Amsterdam, The Netherlands.

*This study was carried out by the Dutch Working Group on Standardization of Rheumatoid Serology. The following participated in this study: $\mathrm{J}$ H de Bruyn, H A L Clasener, H G M Geertzen, I Jankowski, C Kamphorst, J Katchaki, J A M Kerckhaert, G J M Lafeber, P C Limburg, L K J van Romunde, J A M Snijder, M L Westedt.
}

content of the serum further by indicating the intensity of the fluorescence-that is, weak, $\stackrel{\square}{2}$ moderate, or strong. This is of course less time $\overrightarrow{\overrightarrow{0}}$ consuming than the study of a proper dilution series. $\exists$ In view of the considerable number of tests requested this is a factor of importance. ${ }^{6}$ The fact that? international journals accept articles in which the measurement of ANAs is given in titres instead of IUs has also hampered the introduction of the use of reference preparations.

It is well known that high titres $(>1 / 1000)$ are found particularly in systemic lupus erythematosus (SLE) and less frequently in other generalised autoimmune diseases. ${ }^{6-8}$ Quantification is therefore $\frac{D}{0}$ of importance in routine practice, especially in laboratories where more specific but less sensitive $N$ tests such as the $\mathrm{LE}$ cell test and anti-DNA determinations are not performed. Quantification 0 may also be important in the follow up of individual $\omega$ patients with SLE as large fluctuations of the ANA? titre have been observed before and duringo exacerbations. ${ }^{9}$

Until a few years ago most laboratories used rat ${ }^{\circ}$ liver sections as substrate; cultured cells are now often used. Quantitative results expressed in titres may thus show greater interlaboratory variation $\stackrel{\odot}{\square}$ 
than in the earlier days of the IFT. This persuaded the Dutch Working Group on Standardization of Rheumatoid Serology to promote the expression of quantitative ANA determinations in IUs by generating a Dutch reference serum preparation for ANAs (homogeneous). This was related to the first reference preparation of antinuclear factor serum (homogeneous) of WHO (66/233) according to the recommendations given by Johnson et al. ${ }^{10}$ As Molden et al and Nakamura and Rippey in their ANA standardisation studies did not refer to the expression of ANA levels in IUs ${ }^{11} 12$ and Bonifacio et al proposed a method of measurement without serial dilutions, ${ }^{13}$ we thought that it would be valuable to repeat the original studies of Anderson et $a l,{ }^{4}$ using a variety of substrates and different statistical methods.

\section{Materials and methods}

\section{REFERENCE SER UM}

Plasma was obtained during therapeutic plasmapheresis from two patients with SLE. Clotting was promoted by the addition of thrombin. The sera were mixed so that the distribution of IgG and IgM class ANA of the homogeneous type resembled the ratio in the WHO preparation. Ampoules containing $1 \mathrm{ml}$ were freeze dried and sealed.

\section{STAB I LITY TESTING}

Four hundred and eighty ampoules with the freeze dried Dutch reference serum preparation were stored in groups of $\mathbf{2 4}$ for one month, three months, six months, nine months, and one year at four temperatures-namely, $-196^{\circ} \mathrm{C},-20^{\circ} \mathrm{C}, 4^{\circ} \mathrm{C}$, and room temperature. After storage for one year at room temperature no reduction of the ANA titre was detected. Storage at $37^{\circ} \mathrm{C}$ for only three months, however, diminished the solubility of the freeze dried powder. One hundred and twenty ampoules were opened, reconstituted with $1 \mathrm{ml}$ distilled water, and stored for one week, two weeks, one month, three months, and six months at $-20^{\circ} \mathrm{C}$. The results showed no reduction in titre.

\section{CALIBRATION AND REPRODUCIBILITY}

The ANA IFT was performed in six laboratories, in three separate sessions, on three batches of the proposed Dutch reference serum preparation and the WHO reference serum preparation $(66 / 233)$ in twofold replicates, using the WHO fluorescein isothiocyanate conjugated sheep anti-immunoglobulin serum (480010) and the same rat liver as substrate. A standard staining procedure was employed. The reproducibility between days and the homogeneity between batches were satisfactory (Table 1). The
Table 1 Standard deviations of ${ }^{2}$ log titres and $F$ values for the Netherlands antinuclear antibody serum preparation (substrate rat liver)

\begin{tabular}{llll}
\hline & $S D$ & $F$ & $p$ \\
\hline Between days & 0.9 & $12 \cdot 2$ & $<0.001$ \\
Between batches & 1.0 & 16.2 & $<0.001$ \\
\hline
\end{tabular}

SD was about one twofold dilution in each case. The median value for the Dutch reference serum preparation was $200 \mathrm{IU} / \mathrm{ml}$. Use of the same tissue substrate might have been the reason that the $F$ values in Table 1 were still significant (see 'Results, preliminary tests'). The same value of $200 \mathrm{IU} / \mathrm{ml}$ was found for the Dutch reference preparation when fibroblasts were used as substrate.

STATISTICAL ANALYSIS

To test the significance of the results analysis of variance was performed after logarithmic transformation of the titres. Standardised values were expressed as differential ${ }^{2} \log$ titres. Two different test statistics were used:

$$
\text { Classical } F=\frac{S^{2} \text { between labs }}{S^{2} \text { residual }} \text {. }
$$

which should decrease after standardisation. The significance of this decrease was judged by calculating

$$
F^{\prime}=\frac{S^{2} \text { between labs before standardisation }}{S^{2} \text { between labs after standardisation }}
$$

where the $S^{2}$ were corrected for interaction variance. The design of the experiments and the statistical methods have been described in detail by Klein and Janssens. ${ }^{14}$

\section{Results}

\section{PREL I M I N ARY TESTS}

In a first test five laboratories of the Dutch working group measured the ANA level in five test sera and a common reference preparation on three different days. All participants used the same conjugate preparations but were free to choose substrate (rat liver, baby hamster kidney cells, human granulocytes). Simultaneously fibroblasts from the same culture were used as substrate by all participants. Table 2 summarises the results of the statistical analysis. It appeared that when different substrates were used the value of $F$ in the analysis of variance increased after standardisation, showing the expression in IU had no favourable effect. Calculating the $F$ values for rat liver only yielded the same result, but with fibroblasts the decrease of $F$ was significant after omitting one apparent outlier. 
Table 2 Analysis of variance of antinuclear antibody tests on different substrates. All participants used the same conjugate $\overline{\mathrm{Q}}$.

\begin{tabular}{|c|c|c|c|c|c|c|}
\hline \multirow[t]{2}{*}{ Substrate } & \multicolumn{2}{|c|}{ Before standardisation } & \multicolumn{2}{|c|}{ After standardisation } & \multirow[t]{2}{*}{$F^{\prime}$} & \multirow[t]{2}{*}{$p$} \\
\hline & $F$ & $p$ & $F$ & $p$ & & \\
\hline \multicolumn{7}{|l|}{ Rat liver or baby hamster kidney cells } \\
\hline Rat liver only & $51 \cdot 4$ & $<0 \cdot 001$ & $77 \cdot 9$ & $<0 \cdot 001$ & $<1$ & NS \\
\hline Fibroblasts & $73 \cdot 2$ & $<0 \cdot 001$ & $12 \cdot 2$ & $<0 \cdot 001$ & $3 \cdot 2$ & $0.1<\mathrm{p}<0.25$ \\
\hline
\end{tabular}

In a second experiment six laboratories all used the same rat liver preparation and test procedure but their own conjugates, without any effort to calibrate these as recommended by Johnson et al. ${ }^{10}$ As the between day variance was negligible there was only one test day, on which eight sera were read. An effect of only borderline significance was achieved by standardisation (Table 3 ) with $\mathrm{F}^{\prime}$ having a $p$ value between 0.05 and $0 \cdot 1$.

TEST WITH A LARGE GROUP OF

PARTICIPANTS

In this test 26 laboratories agreed to perform on one day IFT titrations on five serum samples from patients with SLE and normal subjects, and the reference serum, using their own substrate and conjugate. The resulting titres were converted into IUs assuming the Dutch reference serum to contain $200 \mathrm{IU} / \mathrm{ml}$. Results using all substrates were accepted, and the 26 laboratories produced 34 result files that could be analysed. Rat liver was used in 17 cases as substrate, $\mathrm{HEp}_{2}$ cells in 11 cases, and fibroblasts in four cases. One laboratory used human granulocytes and another mouse kidney.

Table 3 Analysis of variance of comparative tests for antinuclear antibodies. Rat liver was used by all participants. Each participant used his own conjugate

\begin{tabular}{lrl}
\hline & $F$ & $p$ \\
\hline Before standardisation & 26.8 & $<0.001$ \\
After standardisation & 7.9 & $<0.001$ \\
\hline
\end{tabular}

$F^{\prime}=3 \cdot 7 ; 0 \cdot 05<p<0 \cdot 1$.
Table 4 shows the results analysed according tom substrate. It is seen that a significant effect of standardisation was obtained only with $\mathrm{HEp}_{2}$ cells? On average the total range of readings was reduced by half after standardisation. Fig. 1 gives an example $\overrightarrow{-}$ of the effect of standardisation on the resultsio obtained with one serum. Although with fibroblasts the $F$ values decreased after standardisation, this

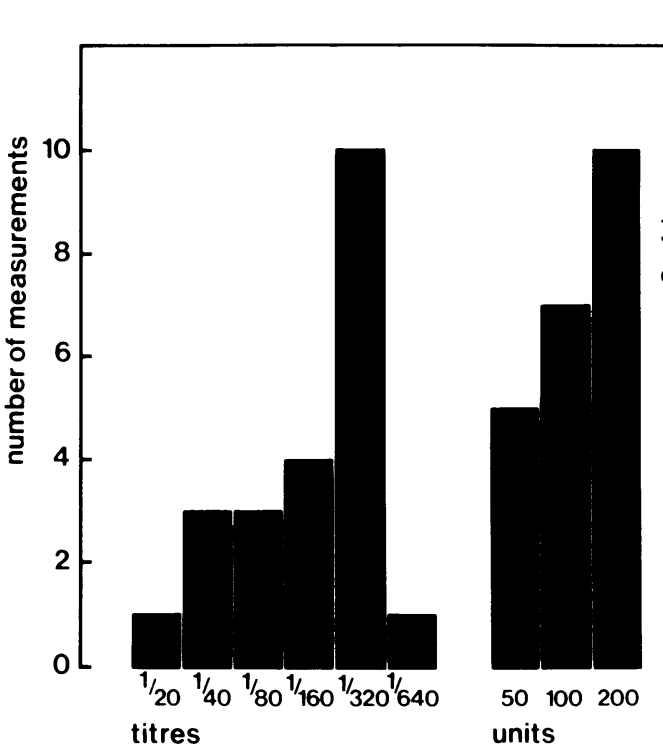

Fig. 1 One serum tested in duplicate on $\mathrm{HEp}_{2}$ cells for antinuclear antibodies (homogeneous type) by 11 laboratories. The results are expressed in titres (left) and in IU (right).

Table 4 Analysis of variance of comparative antinuclear antibody tests performed by 26 participants, each with their own $\mathrm{N}$ procedure(s)

\begin{tabular}{|c|c|c|c|}
\hline Substrate & Number of participants & $F^{\prime}$ & $p$ \\
\hline Rat liver & 17 & $<1$ & NS \\
\hline $\mathrm{HEp}_{2}$ cells & 11 & $4 \cdot 3$ & $0.01<\mathrm{p}<0.025$ \\
\hline $\begin{array}{l}\text { Fibroblasts, human granulocytes. } \\
\text { or mouse kidney }\end{array}$ & 6 & $1 \cdot 2$ & $<0 \cdot 25$ \\
\hline Fibroblasts only & 4 & $<1$ & NS \\
\hline
\end{tabular}


was not significant $\left(F^{\prime}<1\right)$. Again with rat liver the use of a reference preparation did not decrease interlaboratory spread.

\section{Discussion}

ANA determination is often used as a screening method for further serological studies, including the LE cell and tests for antibodies to DNA or to extractable nuclear antigens. In such studies a positive result at a particular serum dilution may give sufficient information. If, however, the ANA determination itself is to be used to suggest further clinical investigation for generalised autoimmune diseases, quantification can be of use. ${ }^{6-8}$ The same applies to longitudinal observations of individual patients; also for the interpretation of scientific studies-for example, comparisons of serological tests in the field of generalised autoimmune diseases or of 'lumping' or 'splitting' in disease classificationquantitative results of ANA determinations are needed. A wide variation in titres between laboratories is evident, especially when different substrates and types of microscopes are used. Nakamura and Rippey recently showed that one serum tested by a number of laboratories had titres between $1 / 8$ and $1 / 640 .^{12}$ For interlaboratory comparison the expression of the results in IUs should therefore be promoted for the same reasons that have been discussed earlier for rheumatoid factor measurements. ${ }^{14}$ The present study has shown that this can be achieved also for homogeneous ANA determinations.

From our experiments it appears that rat liver is unsuitable as a substrate for ANA measurement if interlaboratory comparability is required, and cultured cells are to be preferred. The $\mathrm{HEp}_{2}$ cells gave better results than fibroblasts in interlaboratory comparison.

Thus if the appropriate substrates have been used a reference serum permits the expression of quantitative ANA measurements in IU. The experiments with rat liver, as indicated in Tables 2 and 4, did not suggest that standardisation of conjugates ${ }^{10}$ might give a further improvement in comparability. Use of one batch of rat liver seemed to have a slightly favourable effect (Tables 3 and 4).

A value of 200 IU has been assigned to the Netherlands reference serum, based on comparison with the WHO reference preparation 66/233 using rat liver as a substrate. We propose this value be used also for other substrates. Whether this will always remain valid for particular substrates or methods of cell culture may be a subject for future studies.

A further problem is that whereas the IFT allows the identification of several nuclear staining patterns, the international reference serum preparation only allows comparison for the homogeneous type. ${ }^{4} 1015$ Although not advocated for quantitative comparison, the ANA reference sera provided by the American Arthritis Foundation are of great importance in promoting international agreement on the fluorescence patterns. ${ }^{16}$ These reference sera should be used to provide national and local laboratories with sera of the same type.

Financial support was received from the Foundation Reference Laboratory for Rheumatoid Serology (RELARES).

\section{References}

1 Holborow E J, ed. Standardization in immunofluorescence. Oxford: Blackwell Scientific, 1970.

2 Beutner E H, ed. Defined immunofluorescent staining. Ann NY Acad Sci 1971; 177.

3 Hijmans W, Schaeffer M, eds. Fifth international conference on immunofluorescence and related staining techniques. Ann NY Acad Sci 1975; 254.

4 Anderson S G, Addison I E, Dixon H G. Antinuclear-factor serum (homogeneous): An international collaborative study of the proposed research standard 66/233. Ann NY Acad Sci 1971; 177: 337-45.

5 Anderson S G, Bentzon M W, Houba V, Krag P. International reference preparation of rheumatoid arthritis serum. Bull WHO 1970; 42: 311-8.

6 Feltkamp T E W, Janssens M B J A, Kallenberg C G M, et al. Antinuclear antibody determination in daily practice. In: Kalden J R, Feltkamp T E W, eds. Antibodies to nuclear antigens. Amsterdam: Excerpta Medica, 1982: 11-22.

7 Seligmann M, Cannat A, Hamard M. Studies on antinuclear antibodies. Ann NY Acad Sci 1965; 124: 816-32.

8 Seignalet J, Graafland $H$. Notre expérience des anticorps antinucléaires. I. Les anticorps anti-noyaux entiers. Extrait de Médecine Actuelle 1982; 9: No 10.

9 Swaak A J G, van Rooyen A, Out T, Smeenk R. The qualitative and quantitative aspects of anti-dsDNA antibodies in systemic lupus erythematosus. In: Peeters H. ed. Protides of the biological fluids. Vol 33. Oxford: Pergamon Press, 1985: $297-300$.

10 Johnson G D, Chantler S, Batty I, Holborow E J. Use and abuse of international reference preparations in immunofluorescence. In: Dumonde D C, Steward M W, eds. Laboratory and clinical standardization in rheumatoid arthritis. Part 1. Lancaster: MTP Press, 1978: 93-100.

11 Molden D P, Nakamura R M, Tan E M. Standardization of the immunofluorescence test for autoantibody to nuclear antigens (ANA): use of reference sera of defined antibody specificity. Am J Clin Pathol 1984; 82: 57-66.

12 Nakamura R M, Rippey J H. Quality assurance and proficiency testing for autoantibodies to nuclear antigen. Arch Pathol Lab Med 1985; 109: 109-14.

$\overline{13}$ Bonifacio E, Hollingsworth P N, Dawkins R L. Antinuclear antibody. Precise and accurate quantitation without serial dilutions. J Immunol Methods 1986; 91: 249-55.

14 Klein F, Janssens M B J A. Standardisation of serological tests for rheumatoid factor measurement. Ann Rheum Dis 1987; 46: 674-80.

15 Johnson G D, Holborow E J. Routine immunofluorescent test for serum antinuclear antibodies. Association of Clinical Pathologists Broadsheet 1983; 107: 1-10.

16 Tan E M, Fritzler M J, McDougal J S, et al. Reference sera for antinuclear antibodies. Arthritis Rheum 1982; 25: 1003-5. 